\title{
PERBEDAAN DENSITAS DAN KONTRAS THORAX DENGAN MENGGUNAKAN GRID DAN TANPA GRID
}

\author{
Asih Puji Utami ${ }^{1}$, Justhika Anggriani ${ }^{2}$, Anisa Nur Istiqomah ${ }^{3}$ \\ 1,2,3 Universitas 'Aisyiyah Yogyakarta
}

\begin{abstract}
ABSTRAK
Dalam pemeriksaan thorax melibatkan proyeksi Antero Posterior, Posterior Anterior dan Lateral. Penggunaan bucky yaitu saat dilakukannya pemeriksaan thorax dengan posisi berdiri, menghadap bucky stand proyeksi PA atau Lateral. Penelitian ini bertujuan yaitu membedakan densitas dan kontras radiograf thorax dengan menggunakan grid dan tanpa grid serta merupakan penelitian kuantitatif deskripitif. Radiograf menggunakan grid memiliki densitas cenderung rendah dan kontras tinggi dikarenakan fungsi grid yaitu menyerap radiasi hambur yang keluar dari tabung sinar-X, sehingga gambaran tersebut bisa membedakan antara softtissue, tulang dan mediastinum. Sedangkan pada radiograf tanpa grid memiliki densitas dan kontras yang tinggi pula dikarenakan seluruh radiasi yang keluar dari tabung sinar-X diserap oleh image receptor, sehingga gambaran yang dihasilkan terlalu hitam dan kurang optimal dalam membedakan soft-tissue, tulang dan mediastinum. Dalam pemeriksaan thorax akan lebih optimal dengan menggunakan grid, tetapi bisa juga diatur pada faktor eksposi.
\end{abstract}

\section{Kata Kunci : densitas, kontras, grid, thorax}

\begin{abstract}
Thorax examination involves the projection of Posterior Anterior, Posterior Anterior and Lateral Anterior. When doing a thorax examinationin a standing position, the object must face the bucky PA or Lateral projection stand. The study aims to determine the difference between density and thorax radiograph contrast using a grid and without a grid. The study employed quantitative descriptive method. The results show that radiographs using grids had a low density and high contrast due to the grid function which absorbed scattered radiation coming out of $\mathrm{X}$-ray tubes, so that the image could distinguish between soft tissue, bone and mediastinum. Whereas on a no-grid radiograph, it had high density and contrast because all the radiation coming out of the X-ray tube was absorbed by the image receptor, therefore the resulting image was too black and not optimal in distinguishing soft tissue, bone and mediastinum. In examining the thorax, it will be more optimal by using a grid, but it can also be regulated by exposure factors.
\end{abstract}

Keywords : density, contrast, grid, thorax 


\section{Pendahuluan}

Pemeriksaan radiografi thorax merupakan pemeriksaan yang sering dilakukan. Para mahasiswa memulai pengalaman klinis mereka dengan mengambil radiografi dada. Dada atau thorax merupakan bagian tengah antara leher dan abdomen. Namun, sebelum memulai pengalaman klinis itu, hal yang paling penting yaitu untuk mempelajari dan mengerti anatomi dada, termasuk hubungan yang relativ dari semua anatomi didalam rongga dada. Anatomi radiografi dari thorax terbagi atas 3 bagian: tulang rusuk (bony thorax), sistem pernapasan (respiratory system), dan mediastinum (Bontrager, 2014). Dalam bidang radiodiagnostik, pemeriksaan dada atau thorax selalu dijumpai.

Bucky atau lysolm grid merupakan komponen yang ada pada pesawat sinar-x konvensional dipergunakan untuk mengurangi radiasi hambur. Kelebihan grid lysolm ada pada desain penyusunan lajur-lajur timbal dan konstruksinya. Jika tidak menggunakan grid maka radiasi hambur yang dihasilkan pada proses pembuatan radiograf dapat mengganggu kontras gambar sehingga mengurangi kualitas hasil. Penggunaan grid lysolm diletakkan di atas kaset sebelum dipergunakan untuk melakukan pemeriksaan radiograf (Saputro, 2014). Grid yang digunakan dalam pemeriksaan thorax yaitu moving grid. Moving grid ini terdapat pada meja pemeriksaan dan bucky stand (Bushong, 2013). Menurut Bontrager (2014), karena banyaknya pancaran radiasi yang meningkat dan ketebalan dari jaringan yang terkena radiasi, umumnya disarankan bahwa grid harus digunakan untuk pemeriksaan radiografi bagian tubuh yang lebih tebal dari $10 \mathrm{~cm}$. Penggunaan grid dapat mempengaruhi kualitas citra radiograf, mulai dari densitas, kontras, detail dan ketajaman radiograf. Dalam penelitian ini akan dilakukan pengukuran densitas dan kontras. Pengertian densitas dan kontras sebagai berikut :

1. Densitas

Densitas merupakan derajat kehitaman pada radiograf gambaran. Dengan detail yang cukup, bahkan bagian yang terkecil dari anatomi akan terlihat (Bushong, 2013).

Menurut Carlton (2001), yang diambil dari Karya Tulis Ilmiah (Larasati, 2015) bahwa rentang densitas yang biasa dijumpai pada radiograf adalah 0,25-2,5 dan disebut sebagai densitas guna (Optical Density) atau biasa disingkat OD yaitu densitas yang dapat dilihat langsung oleh mata manusia.

2. Kontras

Kontras merupakan fungsi untuk menampakkan bagian anatomi dari organ. Kontras didefinisikan sebagai perbedaan nilai densitas (derajat kehitaman) pada suatu radiograf. Karena itu kontras sangat penting dalam mengevaluasi kualitas citra radigraf. Kontras merupakan hasil perbedaan atenuasi sinar-X yang menembus jaringan dengan ketebalan struktur yang berbeda, kemampuan menembus jaringan ini sangat dipengaruhi oleh $\mathrm{kV}$ dan mAs (Bushong, 2013).

Untuk mengetahui nilai densitas dengan menggunakan alat pengukur nilai densitas yaitu densitometer. 
Pemeriksaan thorax yang umum dilakukan yaitu menggunakan grid posisi pasien berdiri tegak dan menghadap ke bucky stand, faktor eksposi yang digunakan yaitu untuk $\mathrm{kV}$ 75-100 dan mAs 8-12 dengan FFD 150-180 cm. Namun, jika ketika tidak menggunakan bucky, pasien dengan posisi duduk atau tidur terlentang dengan faktor eksposi yaitu $\mathrm{kV} \mathrm{60-72}$ dan mAs 10-12 dengan FFD 120-150 $\mathrm{cm}$. Tujuan pemeriksaan thorax tanpa menggunakan grid yaitu untuk meminimalisir perubahan posisi pasien dan pergerakan pasien jika pasien yang non kooperatif. Dalam pemeriksaan thorax menggunakan pesawat sinar- $\mathrm{X}$ konvensional. Peneliti disini ingin mengetahui perbedaan densitas dan kontras thorax dengan menggunakan grid dan tanpa menggunakan grid.

Penggunaan bucky atau grid adalah untuk mengurangi radiasi hambur yang keluar dari tabung sinar-X.

\section{Metode}

Jenis penelitian yang diambil yaitu kuantitatif deksriptif, dimana peneliti akan membedakan hasil kualitas radiograf thorax dari aspek densitas dan kontras yaitu saat menggunakan grid dan tanpa grid.

Lokasi dalam pengambilan data bertempat di Laboratorium Radiologi Universitas 'Aisyiyah Yogyakarta, karena peneliti menggunakan phantom sebagai objek dan menggunakan manual processing yang ada di Laboratorium Radiologi Universitas 'Aisyiyah Yogyakarta. Waktu pengambilan data akan dilakukan pada bulan Januari - Mei 2019. Alat yan digunakan dalam penelitian yaitu Phantom, Pesawat sinar-X dengan spesifikasi: 1) Merk: Samsung; 2) Model: DR XGEO GF50; 3) Tahun
Pemasangan: 2016; 4) kV: $150 \mathrm{kV}$; 5) mAs: $640 \mathrm{~mA}$, Grid dengan rasio 1:8, Kaset dan film berukuran $35 \times 35 \mathrm{~cm}$, Densitometer, Manual processing, dan Form hasil pengukuran. Analisis data menggunakan Microsoft Excel 2007.

\section{Hasil dan Pembahasan}

\section{Gambaran Umum Penelitian}

Pada tanggal 06 Mei 2019, telah dilakukan penelitian pada perbedaan densitas dan kontras thorax dengan menggunakan grid dan tanpa grid di Laboratorium Radiologi Universitas 'Aisyiyah Yogyakarta. Penelitian di lakukan dengan menggunakan pesawat sinar-X merk Samsung, objek yang digunakan yaitu phantom, proyeksi yang digunakan yaitu Antero Posterior, menggunakan FFD $150 \mathrm{~cm}$, menggunakan faktor eksposi yang sama yaitu $65 \mathrm{kV}$, mA 200, dan mAs 10, kaset dan film yang digunakan berukuran 35 x $35 \mathrm{~cm}$, eksposi dilakukan 1 kali pada masing-masing radiograf, serta menggunakan manual processing. Grid yang digunakan dalam penelitian ini yaitu grid diam dengan rasio 1:8.

Selama melakukan processing ada beberapa langkah yang dilakukan sehingga gambaran pada radiograf akan terlihat. Dilakukan agitasi selama radiograf berada dicairan developer yaitu 3-4 kali agitasi dengan waktu 6 detik, kemudian dicuci dengan menggunakan air bersih yang mengalir, selanjutnya radiograf tersebut dimasukkan kedalam cairan fixer dengan waktu 2-3 menit. Setelah dilakukan eksposi dan processing kemudian dilakukan pengukuran densitas dan kontras pada radiograf. Densitas dan kontras pada radiograf tersebut diukur dengan menggunakan densitometer yang bermerk pehamed 
DENSOQUICK 2. Total waktu yang dibutuhkan dalam penelitian ini yaitu kurang dari 2 jam.

Dalam pengukuran densitas dan kontras, dilakukan pada beberapa titik yang dibagi menjadi beberapa kategori, yaitu sebagai berikut :

a) Kategori Tulang
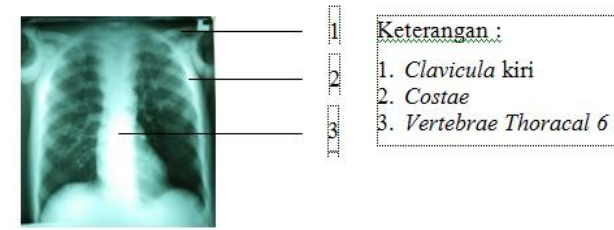

1. Clavicula kiri

. Costae

. Vertebrae Thoracal 6

Gambar 4.1. Daerah Pengukuran Densitas dan Kontras Kategori Tulang

(UnisaYogyakarta, 2019)

b) Kategori Paru-Paru

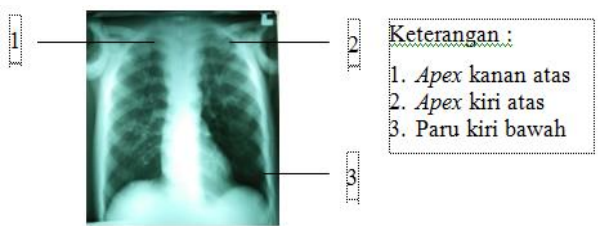

Gambar 4.2. Daerah Pengukuran Densitas dan Kontras Kategori Paru-Paru

(UnisaYogyakarta, 2019)

c) Kategori Jantung

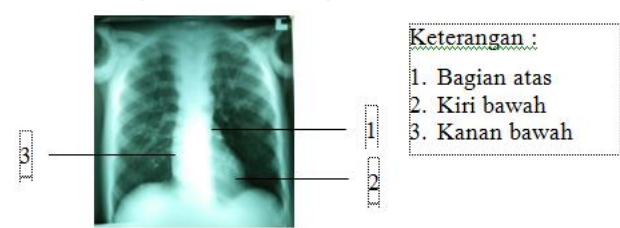

Gambar 4.3. Daerah Pengukuran Densitas dan Kontras Kategori Jantung

(UnisaYogyakarta, 2019)

\section{Hasil Densitas \\ Menggunakan Grid}

Dari hasil pengukuran nilai densitas radiograf thorax dengan menggunakan grid pada titik dari kategori-kategori yang telah ditentukan yaitu sebagai berikut : a) Kategori Tulang

Tabel 4.1. Nilai densitas Radiografi

Thorax Kategori Tulang dengan

Pengukuran Densitometer

\begin{tabular}{|c|c|c|c|c|}
\hline Objek & D1 & D2 & D3 & $\begin{array}{c}\text { D } \\
\text { rata } \\
- \\
\text { rata }\end{array}$ \\
\hline $\begin{array}{l}\text { Clavicu } \\
\text { la Kiri }\end{array}$ & 0,34 & $\begin{array}{c}0,3 \\
3\end{array}$ & 0,33 & 0,33 \\
\hline Costae & 0,55 & $\begin{array}{c}0,5 \\
4\end{array}$ & 0,55 & 0,55 \\
\hline $\begin{array}{l}\text { Vert. } \\
\text { Thorac } \\
\text { al } 6\end{array}$ & 0,16 & $\begin{array}{c}0,1 \\
6\end{array}$ & 0,19 & 0,17 \\
\hline & & & $\begin{array}{l}\text { Rata } \\
\text {-rata }\end{array}$ & 0,35 \\
\hline
\end{tabular}

Berdasarkan tabel 4.1 didapatkan nilai densitas radiograf thorax menggunakan grid pada kategori tulang yang dilakukan pengukuran pada beberapa titik objek sebanyak 3 kali menghasilkan densitas radiograf sejumlah 0,35. Dari hasil densitas tersebut didapatkan nilai yang tertinggi yaitu pada daerah Costae memiliki nilai yang tertinggi sebesar 0,55 dan nilai yang terendah yaitu pada daerah Vertebrae Thoracal 6 sebesar 0,17 pada radiograf menggunakan grid. 
b) Kategori Paru-Paru

Tabel 4.2. Nilai densitas Radiografi

Thorax Kategori Paru-Paru dengan

Pengukuran Densitometer c) Kategori Jantung

Tabel 4.3. Nilai densitas Radiografi

Thorax Kategori Jantung dengan

Pengukuran Densitometer

\begin{tabular}{|c|c|c|c|c|}
\hline Objek & D1 & D2 & D3 & $\begin{array}{c}\text { D } \\
\text { rata- } \\
\text { rata }\end{array}$ \\
\hline $\begin{array}{l}\text { Bagian } \\
\text { Atas }\end{array}$ & 0,04 & 0,05 & 0,05 & 0,05 \\
\hline Kiri & 0,08 & 0,09 & 0,10 & 0,09 \\
\hline
\end{tabular}

Bawah

Atas

\begin{tabular}{ccccc}
\hline Objek & D1 & D2 & D3 & $\begin{array}{c}\text { D } \\
\text { rata- } \\
\end{array}$ \\
& & & & rata \\
\hline Apex & 0,66 & 0.65 & 0,66 & 0,65
\end{tabular}

Kanan

\begin{tabular}{lllll}
\hline Apex Kiri & 0,02 & 0,02 & 0,02 & 0,02
\end{tabular}

Atas

\begin{tabular}{lllll}
\hline Kanan & 0,50 & 0,48 & 0,49 & 0,49 \\
Bawah & & & & \\
\end{tabular}

Paru Kiri $\quad 0,41 \quad 0,41 \quad 0,40 \quad 0,41$

Bawah

$\begin{array}{ll}\text { Rata- } & 0,36 \\ \text { rata } & \end{array}$

Berdasarkan tabel 4.2 didapatkan nilai densitas radiograf thorax menggunakan grid pada kategori paruparu yang dilakukan pengukuran pada beberapa titik objek sebanyak 3 kali menghasilkan densitas radiograf sejumlah 0,36. Dari hasil densitas tersebut didapatkan nilai yang tertinggi yaitu pada daerah Apex Kanan Atas memiliki nilai yang tertinggi sebesar 0,65 dan nilai yang terendah yaitu pada daerah Apex Kiri Atas sebesar 0,17 pada radiograf menggunakan grid.

$\begin{array}{ll}\text { Rata- } & 0,21 \\ \text { rata } & \end{array}$

Berdasarkan tabel 4.3 didapatkan nilai densitas radiograf thorax menggunakan grid pada kategori jantung yang dilakukan pengukuran pada beberapa titik objek sebanyak 3 kali menghasilkan densitas radiograf sejumlah 0,21. Dari hasil densitas tersebut didapatkan nilai yang tertinggi yaitu pada daerah Kanan Bawah memiliki nilai yang tertinggi sebesar 0,49 dan nilai yang terendah yaitu pada daerah Bagian Atas sebesar 0,05 pada radiograf menggunakan grid.

Berdasarkan hasil pengukuran densitas diatas, didapatkan nilai densitas rata-rata yang berbeda pada setiap kategori. Sehingga dapat dikelompokkan sebagai berikut : 
Tabel. 4.4. Nilai Densitas Dari Semua Kategori Pada Radiograf Menggunakan Grid

\begin{tabular}{cc}
\hline Kategori & Densitas \\
\hline Tulang & 0,35 \\
\hline Paru-Paru & 0,36 \\
\hline Jantung & 0,21 \\
\hline
\end{tabular}

Dari tabel 4.4 dapat dilihat bahwa dari ketiga kategori yang memiliki nilai densitas tertinggi terdapat pada kategori paru-paru sebesar 1,62 dan nilai densitas terendah terdapat pada kategori jantung sebesar 0,21.

\section{Hasil Densitas Thorax Tanpa Grid}

Dari hasil pengukuran nilai densitas radiograf thorax tanpa grid pada titik dari kategori-kategori yang telah ditentukan yaitu sebagai berikut :

a) Kategori Tulang

Tabel 4.5. Nilai densitas Radiografi Thorax Kategori Tulang dengan Pengukuran Densitometer

\begin{tabular}{lcccc}
\hline \multicolumn{1}{c}{ Objek } & D1 & D2 & D3 & $\begin{array}{c}\text { D } \\
\text { rata }\end{array}$ \\
& & & & $\begin{array}{c}\text { - } \\
\text { rata }\end{array}$ \\
& & & & \\
\hline Clavicula & 1,2 & 1,2 & 1,25 & 1,25 \\
Kiri & 4 & 5 & & \\
\hline Costae & 1,2 & 1,2 & 1,25 & 1,25 \\
& 5 & 5 & & \\
\hline Vert. & 1,0 & 1,0 & 1,03 & 1,03 \\
Thoracal 6 & 3 & 3 & & \\
\hline & & & Rata & 0,21 \\
& & & -rata & \\
\cline { 3 - 5 } & & &
\end{tabular}

Berdasarkan tabel 4.5 didapatkan nilai densitas radiograf thorax tanpa grid pada kategori tulang yang dilakukan pengukuran pada beberapa titik objek sebanyak 3 kali menghasilkan densitas radiograf sejumlah 0,21. Dari hasil densitas tersebut didapatkan nilai yang tertinggi yaitu pada daerah Costae dan Clavicula Kiri memiliki nilai yang tertinggi sebesar 1,25 dan nilai yang terendah yaitu pada daerah Vertebrae Thoracal 6 sebesar 1,03 pada radiograf tanpa grid.

b) Kategori Paru-Paru

Tabel 4.6. Nilai densitas Radiografi Thorax Kategori Paru-Paru dengan Pengukuran Densitometer

\begin{tabular}{|c|c|c|c|c|}
\hline Objek & D1 & D2 & D3 & $\begin{array}{c}\text { D rata- } \\
\text { rata }\end{array}$ \\
\hline Apex & 1,70 & 1,70 & 1,70 & 1,70 \\
\hline \multicolumn{5}{|l|}{ Kanan } \\
\hline \multicolumn{5}{|l|}{ Atas } \\
\hline Apex & 1,51 & 1,51 & 1,51 & 1,51 \\
\hline \multicolumn{5}{|l|}{ Kiri } \\
\hline \multicolumn{5}{|l|}{ Atas } \\
\hline Paru & 1,65 & 1,67 & 1,67 & 1,66 \\
\hline \multicolumn{5}{|l|}{ Kiri } \\
\hline \multicolumn{5}{|l|}{ Bawah } \\
\hline & & & $\begin{array}{c}\text { Rata- } \\
\text { rata }\end{array}$ & 1,62 \\
\hline
\end{tabular}

Berdasarkan tabel 4.6 didapatkan nilai densitas radiograf thorax tanpa grid pada kategori paru-paru yang dilakukan pengukuran pada beberapa titik objek sebanyak 3 kali menghasilkan densitas radiograf sejumlah 1,62. Dari hasil densitas tersebut didapatkan nilai yang tertinggi 
yaitu pada daerah Apex Kanan Atas memiliki nilai yang tertinggi sebesar 1,70 dan nilai yang terendah yaitu pada daerah Apex Kiri Atas sebesar 1,51 pada radiograf tanpa grid.

c) Kategori Jantung

Tabel 4.7. Nilai densitas Radiografi

Thorax Kategori Jantung dengan Pengukuran Densitometer

\begin{tabular}{lcccc}
\hline Objek & D1 & D2 & D3 & $\begin{array}{c}\text { D } \\
\text { rata- } \\
\end{array}$ \\
& & & & rata \\
\hline Bagian & 1,31 & 1,31 & 1,31 & 1,31 \\
Atas & & & & \\
\hline Kiri & 1,52 & 1,53 & 1,53 & 1,52 \\
Bawah & & & & \\
\hline
\end{tabular}

\begin{tabular}{lllll}
\hline Kanan & 1,67 & 1,67 & 1,67 & 1,67
\end{tabular}

Bawah

Rata- 1,5
rata

Berdasarkan tabel 4.7 didapatkan nilai densitas radiograf thorax tanpa grid pada kategori jantung yang dilakukan pengukuran pada beberapa titik objek sebanyak 3 kali menghasilkan densitas radiograf sejumlah 1,5. Hasil densitas rata-rata pada area Bagian Atas sebesar 1,31, untuk area Kiri Bawah sebesar 1,52, dan untuk area Kanan Bawah sebesar 1,67. Dari hasil densitas tersebut area Kanan Bawah memiliki nilai yang tertinggi pada radiograf tanpa grid.

Berdasarkan hasil pengukuran densitas diatas, didapatkan nilai densitas rata-rata yang berbeda pada setiap kategori. Sehingga dapat dikelompokkan sebagai berikut :
Tabel 4.8. Nilai Densitas Dari Semua

Kategori Pada Radiograf Tanpa Grid

$$
\text { Kategori Densitas }
$$

\begin{tabular}{cc}
\hline Tulang & 0,21 \\
\hline Paru-Paru & 1,62 \\
\hline Jantung & 1,5
\end{tabular}

Dari tabel 4.8 dapat dilihat bahwa dari ketiga kategori yang memiliki nilai densitas tertinggi terdapat pada kategori paru-paru sebesar 1,62 dan nilai densitas terendah terdapat pada kategori tulang sebesar 0,21.

\section{Hasil Kontras \\ Thorax \\ Menggunakan Grid}

Dari hasil pengukuran densitas dan kontras melalui pengukuran dengan menggunakan densitometer pada radiograf, dari penelitian perbedaan citra radiograf thorax dengan proyeksi Antero Posterior antara menggunakan grid dan tanpa grid didapatkan hasil kontras sebagai berikut :

a) Kategori Tulang

Tabel 4.9. Nilai Kontras Radiografi

Thorax Kategori Tulang

Menggunakan Grid

\begin{tabular}{cc}
\hline Objek & D rata-rata \\
\hline Clavicula kiri & 0,33 \\
\hline Costae & 0,55 \\
\hline Vert. Thoracal 6 & 0,17 \\
\hline Kontras & \\
Radiograf & 0,38 \\
(Dmax-Dmin) & \\
\hline
\end{tabular}

Berdasarkan tabel 4.9 didapatkan nilai kontras radiograf thorax menggunakan grid pada kategori tulang yang dilakukan perhitungan dari rumus 
Dmax-Dmin menghasilkan kontras radiograf sebesar 0,38.

b) Kategori Paru-Paru

Tabel 4.10. Nilai Kontras Radiografi Thorax Kategori Paru-Paru Menggunakan Grid

\begin{tabular}{cc}
\hline Objek & D rata-rata \\
\hline Apex Kanan Atas & 0,65 \\
\hline Apex Kiri Atas & 0,02 \\
\hline Paru Kiri Bawah & 0,41 \\
\hline Kontras & \\
Radiograf & 0,39 \\
(Dmax-Dmin) & \\
\hline
\end{tabular}

Berdasarkan tabel 4.10 didapatkan nilai kontras radiograf thorax menggunakan grid pada kategori paruparu yang dilakukan perhitungan dari rumus Dmax-Dmin menghasilkan kontras radiograf sebesar 0,39.

c) Kategori Jantung

Tabel 4.11. Nilai Kontras Radiografi

Thorax Kategori Jantung Menggunakan Grid

\begin{tabular}{cc}
\hline Objek & D rata-rata \\
\hline Bagian Atas & 0,05 \\
\hline Kiri Bawah & 0,09 \\
\hline Kanan Bawah & 0,49 \\
\hline Kontras & \\
Radiograf & 0,44 \\
(Dmax-Dmin) & \\
\hline
\end{tabular}

Berdasarkan tabel 4.11 didapatkan nilai kontras radiograf thorax menggunakan grid pada kategori jantung yang dilakukan perhitungan dari rumus Dmax-Dmin menghasilkan kontras radiograf sebesar 0,44.

Berdasarkan hasil perhitungan kontras diatas, didapatkan nilai kontras radiograf yang berbeda pada setiap kategori. Sehingga dapat dikelompokkan sebagai berikut :

Tabel 4.12. Nilai Kontras Dari Semua

Kategori Pada Radiograf Menggunakan Grid

\begin{tabular}{cc}
\hline Kategori & Kontras \\
\hline Tulang & 0,38 \\
\hline Paru-Paru & 0,39 \\
\hline Jantung & 0,44 \\
\hline
\end{tabular}

Dari tabel 4.12 dapat dilihat bahwa dari ketiga kategori yang memiliki nilai kontras tertinggi terdapat pada kategori jantung sebesar 0,44 dan nilai kontras terendah terdapat pada kategori tulang sebesar 0,38 .

\section{Hasil Kontras Thorax Tanpa Grid}

Dari hasil pengukuran densitas dan kontras melalui pengukuran dengan menggunakan densitometer pada radiograf, dari penelitian perbedaan citra radiograf thorax dengan proyeksi Antero Posterior antara menggunakan grid dan tanpa grid didapatkan hasil kontras sebagai berikut :

a) Kategori Tulang

Tabel 4.13. Nilai Kontras Radiografi Thorax Kategori Tulang Tanpa Grid Objek D rata-rata

\begin{tabular}{cc}
\hline Clavicula kiri & 1,25 \\
\hline Costae & 1,25 \\
\hline Vert. Thoracal 6 & 1,03 \\
\hline Kontras & \\
Radiograf & 0,22 \\
(Dmax-Dmin) & \\
\hline
\end{tabular}


Berdasarkan tabel 4.13 didapatkan nilai kontras radiograf thorax tanpa grid pada kategori tulang yang dilakukan perhitungan dari rumus Dmax-Dmin menghasilkan kontras radiograf sebesar 0,22.

b) Kategori Paru-Paru

Tabel 4.14. Nilai Kontras Radiografi Thorax Kategori Paru-Paru Tanpa Grid

\begin{tabular}{cc}
\hline Objek & D rata-rata \\
\hline Apex Kanan Atas & 1,70 \\
\hline Apex Kiri Atas & 1,51 \\
\hline Paru Kiri Bawah & 1,66 \\
\hline Kontras & \\
Radiograf & 1,19 \\
(Dmax-Dmin) & \\
\hline
\end{tabular}

Berdasarkan tabel 4.14 didapatkan nilai kontras radiograf thorax tanpa grid pada kategori paru-paru yang dilakukan perhitungan dari rumus Dmax-Dmin menghasilkan kontras radiograf sebesar 1,19.

c) Kategori Jantung

Tabel 4.15. Nilai Kontras Radiografi Thorax Kategori Jantung Tanpa Grid

Objek D rata-rata

\begin{tabular}{cc}
\hline Bagian Atas & 1,31 \\
\hline Kiri Bawah & 1,52 \\
\hline Kanan Bawah & 1,67 \\
\hline Kontras & \\
Radiograf & 0,36 \\
(Dmax-Dmin) & \\
\hline
\end{tabular}

Berdasarkan tabel 4.15 didapatkan nilai kontras radiograf thorax tanpa grid pada kategori jantung yang dilakukan perhitungan dari rumus
Dmax-Dmin menghasilkan kontras radiograf sebesar 0,36.

Berdasarkan hasil perhitungan kontras diatas, didapatkan nilai kontras radiograf yang berbeda pada setiap kategori. Sehingga dapat dikelompokkan sebagai berikut :

Tabel 4.16. Nilai Kontras Dari Semua Kategori Pada Radiograf Tanpa Grid

\begin{tabular}{cc}
\hline Kategori & Kontras \\
\hline Tulang & 0,22 \\
\hline Paru-Paru & 1,19 \\
\hline Jantung & 0,36 \\
\hline
\end{tabular}

Dari tabel 4.16 dapat dilihat bahwa dari ketiga kategori yang memiliki nilai kontras tertinggi terdapat pada kategori jantung sebesar 0,44 dan nilai kontras terendah terdapat pada kategori tulang sebesar 0,38.

Berdasarkan pengukuran nilai densitas dan kontras pada radiograf thorax dengan menggunakan grid dan tanpa grid, dapat dilihat bahwa keduanya memiliki perbedaan yang sangat signifikan. Namun dapat juga dilihat pada hasil radiograf thorax sebagai berikut: (a)

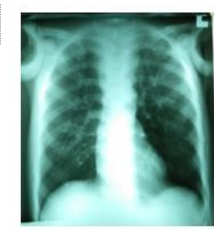

(b)

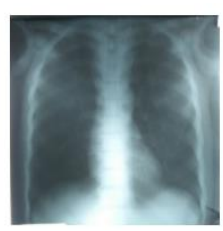

Gambar 4.4. (a) Radiograf dengan Grid dan (b) Radiograf Tanpa Grid(Unisa Yogyakarta, 2019)

Dari hasil pengukuran nilai densitas thorax dengan menggunakan grid dan tanpa grid yang didapatkan hasil yang sangat signifikan perbedaannya. Kedua radiograf diukur dengan menggunakan densitometer pada titik objek yang 
dibagi menjadi 3 kategori, yaitu kategori tulang, kategori paru-paru dan kategori jantung. Pada radiograf thorax dengan menggunakan grid memiliki nilai densitas rata-rata dengan kategori tulang sebesar 0,35 , pada kategori paru-paru sebesar 0,36, dan kategori jantung sebesar 0,21. Kemudian pada radiograf thorax tanpa grid memiliki nilai densitas rata-rata dengan kategori tulang sebesar 0,21 , pada kategori paru-paru sebesar 1,62, dan kategori jantung sebesar 1,67.

Menurut Carlton (2001), yang diambil dari Karya Tulis Ilmiah (Larasati, 2015) bahwa rentang nilai densitas radiograf yaitu 0,25-2,5. Sedangkan kedua hasil radiograf thorax menghasilkan nilai densitas rata-rata 0,21-1,67. Nilai densitas yang paling rendah terdapat pada radiograf thorax dengan menggunakan grid pada kategori jantung yaitu 0,21 dan pada radiograf thorax tanpa grid pada kategori tulang 0,21. Sedangkan untuk nilai densitas yang paling tinggi terdapat pada radiograf thorax tanpa grid pada kategori jantung dengan nilai 1,67. Akan tetapi, dari kedua radiograf tersebut yang cenderung memiliki nilai densitas besar terdapat pada radiograf thorax tanpa grid.

Menurut peneliti, besarnya nilai densitas pada radiograf tanpa grid menyebabkan radiasi hambur yang dikeluarkan oleh tabung sinar-x diterima semuanya oleh image receptor atau film, sehingga menyebabkan gambaran cenderung menghitam. Akan tetapi, nilai densitas yang didapatkan pada kedua radiograf tersebut masih dikatakan aman, karena tidak lebih dari nilai yang sudah ditentukan.

Pada perhitungan nilai kontras terhadap radiograf thorax dengan menggunakan grid dan tanpa grid memiliki perbedaan yang signifikan pula. Pada radiograf dengan menggunakan grid memiliki nilai kontras yaitu pada kategori tulang sebesar 0,38, pada kategori paru-paru sebesar 0,39, dan pada kategori jantung sebesar 0,44. Sedangkan pada radiograf tanpa menggunakan bucky memiliki nilai kontras sebagai berikut pada kategori tulang sebesar 0,22, pada kategori paru-paru sebesar 1,19, dan pada kategori jantung sebesar 0,39. Nilai kontras radiograf tersebut didapatkan dari persamaan DmaxDmin. Dari kedua radiograf ini dapat dilihat bahwa nilai kontras yang terbesar terdapat pada radiograf thorax tanpa grid pada kategori paru-paru.

Penilaian kontras dapat dilihat dengan dua cara yaitu secara subjektif dan secara objektif. Kontras subjektif yaitu perbedaan persepsi atau dapat melihat hasil radiograf thorax antara menggunakan grid dan tanpa grid secara langsung, sehingga bisa langsung menilai perbedaan densitas dan kontras dari radiograf tersebut. Sedangkan kontras objektif yaitu perbedaan gambaran hitam dan putih yang diukur, sehingga untuk mengetahui nilai densitas dan kontras dari radiograf thorax menggunakan grid dan tanpa grid harus diukur dengan menggunakan alat densitometer.

Menurut peneliti, bahwa penggunaan grid mempengaruhi densitas dan kontras suatu radiograf pada objek yang lebih tebal. Sehingga perlu juga untuk memperhatikan faktor-faktor lain seperti cairan processing, faktor eksposi, dan sebagainya.

Berdasarkan penjelasan diatas, dapat dilihat bahwa densitas dan kontras pada radiograf thorax proyeksi Antero 
Posterior dengan menggunakan grid dan tanpa grid memiliki perbedaan sebagai berikut :

Tabel 4.17. Perbedaan Nilai Densitas dan Kontras Radiograf Thorax Menggunakan Grid dan Tanpa Grid

\begin{tabular}{|c|c|c|c|c|}
\hline \multirow{2}{*}{ Kategori } & \multicolumn{2}{|c|}{ Mengounakan Grid } & \multicolumn{2}{|c|}{ Tanpa Grid } \\
\hline & Densitas & Kontitas & Densitas & Kontras \\
\hline Tulang & 0,35 & 0,38 & 0,21 & 0,22 \\
\hline Partu & 0,36 & 0,39 & 1,26 & 1,19 \\
\hline Jantung & 0,21 & 0,44 & 1,5 & 0,36 \\
\hline
\end{tabular}
sedangkan pada radiograf tanpa grid memiliki densitas yang tinggi dan kontras yang tinggi pula.

Pada tabel radiograf dengan menggunakan grid memiliki densitas cenderung rendah dan kontras tinggi dikarenakan fungsi dari grid yaitu menyerap radiasi hambur yang keluar dari tabung sinar- $X$, sehingga gambaran tersebut bisa membedakan antara soft-tissue, tulang dan mediastinum. Sedangkan pada tabel radiograf tanpa menggunakan grid memiliki densitas yang tinggi dan kontras yang tinggi pula dikarenakan seluruh radiasi yang keluar dari tabung sinar-X langsung diserap oleh image receptor, sehingga gambaran yang dihasilkan terlalu hitam dan kurang optimal dalam membedakan soft-tissue, tulang dan mediastinum.

\section{Simpulan}

1. Didapatkan hasil densitas pada radiograf thorax dengan menggunakan grid pada kategori tulang sebesar 0,35, kategori paruparu 0,36, dan kategori jantung 0,21.

2. Densitas pada radiograf thorax tanpa grid pada kategori tulang sebesar 0,21, pada kategori paruparu 1,62, dan kategori jantung 1,5.

3. Didapatkan hasil kontras pada radiograf thorax dengan menggunakan grid pada kategori tulang sebesar 0,38, pada kategori paru-paru 0,39, dan kategori jantung 0,44 .

4. Kontras pada radiograf thorax tanpa grid pada kategori tulang sebesar 0,22 , pada kategori paru-paru 1,19, dan kategori jantung 0,36.

5. Pada radiograf dengan menggunakan grid cenderung memiliki densitas yang rendah dan nilai kontras yang tinggi, sedangkan pada radiograf tanpa grid memiliki densitas yang tinggi dan kontras yang tinggi pula.

\section{Saran}

1. Dalam melakukan pemeriksaan thorax sebaiknya menggunakan grid atau bucky agar densitas dan kontras yang dihasilkan bisa lebih optimal, meskipun pada perangkat komputer dapat dimanipulasi.

2. Jika tidak memungkinkan untuk menggunakan grid atau bucky, dapat diatur pada faktor eksposi yang digunakan.

\section{Daftar Pustaka}

Al-Qur'an, Surah Ibrahim, ayat 7

Bontrager, Kenneth, John P. Lampignano.2014. Textbook of Radiographic Positioning and Related Anatomy. Eighth edition. ELSEVIER : USA.

Bushong, Stewart C. 2013. Radiology Science For Technologists. Tenth Edition. St Louis : Mosby

Utami, Asih, Fisnandya Meita. 2018. Panduan Penyusunan Karya Tulis Ilmiah (KTI) Program Studi DIII Radiologi. Yogyakarta : UNISA 